\title{
EXAMINATION OF ETHICAL PROCUREMENT THROUGH ENTERPRISE EXAMPLES
}

\author{
Beáta Sz. G. Pató, Anna Freund \\ University of Pannonia, Veszprém, Hungary \\ E-mail: patog@vnet.hu, freund.anna@amicustrade.hu
}

\begin{abstract}
Today's business world is affected by the 21st century's processes, like globalization, fluent online attendance, digitalization and their direct consequence depersonalisation. The authors are motivated by these facts and want to vivify the ,old fashioned" correct business models and find the indispensable parameter of the well-functioning economy, in one word today's equivalent of ,, honorable gentlemen”. The assumed key to success could be useful for the for-profit sector because not only profit can be the impelling in the professional life of a corporation. The human value added is one of the most important keystones of thrift. The aim to establish a balance between economic and ethical behaviour of corporations has been enounced serving the interest of all participants, consumers, corporations and society.

The before natural thought values seem nowadays to turn into something different or to be neglected. As a consequence the question has been raised, if society has the force to establish and improve Ethics, will it be able to destroy it as well?!

The main focus of the research is therefore the mapping of criteria and marks which belong to on the competitive market successful enterprises whose procurement decisions are ethical as well. These marks can be formal or informal. The results of the research show well that there are parameters of a company, for example, a code of conduct within guidelines concerning the procurement or procedure manuals in which also ethical issues appear in a formal way. From another point of view there are informal signs like customs arising from the corporate culture, daily routine or just human behaviour and convincement of the management and procurement employees that also support the ethical performance of the company. The results of the research can serve as best practice for the other enterprises too in their daily appearance on the market. Particularly in that area the company's most important goal is "gaining profit" which can have next to itself another value added the "fair work". Its role is to lead the attention to the statement that next to fair working on the market profit can be produced as well. The researchers consider it important that the companies who have already kept in mind the ethical procurement could gain a feedback, an inspiration or even new ideas to follow their work.
\end{abstract}

Key words: business ethics, procurement issues, corporation's behaviour, sustainable procurement.

\section{Introduction}

At first it is important to clear why the ethical behaviour in procurement methods was chosen as the topic of the study. Today, thanks to globalization processes taking place in the world, enterprises can come into contact with various parts of the world.

This research is supposed to monitor the connection between Ethics and this functional part of companies, purchasing. Nowadays the topic seems to be increasingly important in theoretical areas, so the authors wanted to gain information about its relevance in business life as well. Purchasing, one of the functional sections of corporation is monitored in the study. The choice of the partner area of Ethics is based on the importance of purchasing in business life. Its relationships with many intern and extern partners of the company triggered the main questions of the study. By and large connection network of purchasing can be drawn into both 
Beáta Sz. G. PATÓ, Anna FREUND. Examination of ethical procurement through enterprise examples

PROBLEMS

OF MANAGEMENT

IN THE $21^{\text {st }}$ CENTURY Vol. 11, No. 1, 2016

30

directions and due to this fact it worth to be concerned with this current topic. Because of this attribute purchasing collages are surrounded by many impulses, which can change their everyday decision making. At the analysis of purchasing methods due to the number of the variable stakeholders it is worth to concentrate on the ethical impellent because the object of Ethics is the human action. (Turay, 2005).

\section{Problem of Research}

Different companies shape up their working methods and business contact based on different principles, values and opportunities. The procurement is one part of the supply chain which can be influenced by another supply chain members like suppliers or partner companies, of course, according to its role in the supply chain. In other words, the supplier, the purchasing principles and values are chosen by the management making along their ethical behaviour - in the spirit of sustainability - and it can serve the development of the further ethical behaviour and partnerships. Today's economic environment is a significant profit-oriented one and it is very important to raise awareness to the operational opportunities that support sustainability, but from the researchers view this can be difficult achieved without the absence of ethical behaviour.

So the initial problem is, how the human ethical behaviour can be identified and controlled in the field of procurement when they may have acted either formal or informal appearance, and that are the bearers of them in the working methods of the company. It has made the study making part a bit difficult that the honest answers of the interviewees could be gained only by the discreet composition of the interview questions and the subject had to be several times walked around.

\section{Literature Overview}

\section{Purchasing}

Purchasing is one of the complex functional sections at a company's structure. Purchasing consists of more components, like planning and configuring purchasing strategy, the real transaction and following-up of every important part of the mechanism. "Purchasing is supposed to select the right supplier, have contracts signed, control and develop contiguously the supplier's crew and coordinate the common work with the other parts of the company." (Majoros 1999, p15)

The scope of acquisition extends on the various production steps, focuses on reducing production downtime, fully meeting customer needs, and the costs resulting from waste, faulty parts and transportation. Work instructions or job descriptions - either in 2D or 3D format - can best define the responsibilities and processes of these jobs belonging to different functional areas, There is a chance to fully meet customers' needs if we rely on these documents. (Pató, 2015)

Another definition of this unit is well known from the logistics as the 7M conception's remade version. It says that the aim of purchasing is to give free run of the right qualified products and services, in the right quantity, time, price and to gain them from the right supplier. (Kovács, 2004)

The main role of purchasing is to have the purchasable needs of the given company covered. On the other hand, material supply is not as important for every organization as it is thought to be. "But in the most cases it is really relevant, because more than the half of the income of an average company is paid for materials, supply and services." (Baily, 1994, p16) It can be also ascertained that purchasing is an indispensable part of a producer company. 
Purchasing is not only determined by intern needs, but also several external environmental factors. The latest studies (Kovács\&Pató, 2014) attended, highlighted to the impacts of climate change and as a consequence distribution processes and so purchasing might be under the influence of these changes.

Based on the definition, it is true, that there is some kind of transaction happening between the company and the partner.

On one hand, the financial side of the transaction is one of the most important goals of the economic organization, but there are other parts of this process to be appreciated. To have the needed products or materials delivered in time, at the right place can be as important as the fact that the price is at the optimum.

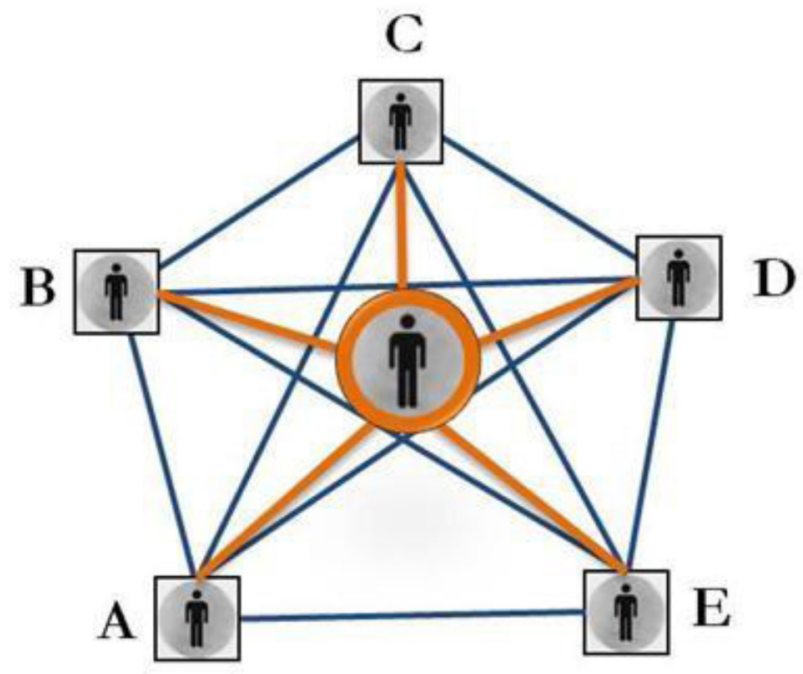

Figure 1: Central placement of purchasing (based on Borgulya, 2007, p. 87).

Figure 1. illustrates the role of purchasing. From there the placement of purchasing within the company shows us a connection network extended in every direction. Purchasing is connected to the production, controlling, finance and to all of the corporation's units (Gaál, 2007). Neither a centralized nor decentralized purchasing system means success for the first time. In many companies the combination of the two options is applied and seems to work quiet optimal as well. On the first figure a decentralized purchasing environment can be seen. The purchasing colleague in the orange circle in the middle of the picture is connected to all of the before mentioned other units of the company. He is supposed to communicate and negotiate with all of the other colleagues and plays the role of the central character in the communication network (Borgulya, 2007).

Sometimes centralization makes the company's life easier because purchasing is lead from one point and this group is the one and only who takes all responsibility in every purchase method. Despite all this, this system might not work because of the wrong pursuit of cooperation of the participants. Another danger of it is that the purchasers also might not have enough experience to choose the optimal inputs for the different units of the company.

To solve problems like this, the other option can come alive. Every single part of the company can take the responsibility for their orders in the case if a decentralized purchasing system works there. Possible suppliers should be searched, examined and then followed-up by the colleagues of all units. The danger of this alternative is hidden in the administrative and discussion part of this work. For example, some engineers are not talented enough 
Beáta Sz. G. PATÓ, Anna FREUND. Examination of ethical procurement through enterprise examples

PROBLEMS

OF MANAGEMENT

IN THE $21^{\text {st }}$ CENTURY Vol. 11, No. 1, 2016

32

to communicate and reach their interest without having losses on the financial part of the transaction. It seems to be imaginable, that the personalized combination of the alternatives can follow to success in every corporation and to find the right rate of both, this should be an experimental way for the company.

The exercises of purchasing are featured by the so called five "conformity parameters". Before we get to know the definition of the right quality, quantity, time, supplier and price, we need to clarify the meaning of "the right" appellation. According to Professor Veress (Veress, 2010 ) in case of many companies conformity and quality have the same meaning. Quality has to be interpreted as a value which is established by satisfied demand. In opposite of this conformity is a measurable phenomenon, where a written requirement system has to be followed. The results of a conformity assessment are compared with the requirements and with that information the product or service so can be judged. In this situation only the exact correspondence of the results is the aim of the company. In such high production it is the relevant way to choose, because of the amplitude of the production movements. But how many companies do you suppose choose conformity instead of quality by the configuration of a product? The rate is incredibly high, so in the following section the five basic conformity parameters will be introduced.

\section{Optimal Quality}

Business participants have already for many years responded to the demand which has been established by attendance of conformity and quality in the business life. The TÜV Rheinland Group, founded in 1872 and headquartered in Cologne, is a leading provider of technical services worldwide. "The Group's mission and guiding principle is to achieve sustained development of safety and quality in order to meet the challenges arising from the interaction between man, technology and the environment." (http://tuv.com latest download: 02. 11. 2015) The most admitted certificates are ISO 9001 and ISO 14001 . The quality system of a company is regularized by the certificate ISO 9001. So the quality assurance at an organization is monitored all the time and has to answer the requirements of ISO 9001. Mentioning the other certificate is no coincidence. Companies are supposed to get used to caring about the environment and the impacts of manufacturing their products. To cope with the challenges of today's business, social, economic, environmental, political and legal requirements, ISO 14001 can be the first helping step to a corporation. ISO 14001 environmental management system offers a framework for voluntary development of conservation measures - from things like saving energy to climate protection and waste removal. So the corporations started to develop their quality assurance based on gaining these certificates. The right quality is born first by the manufacturer, so the quality is a parameter of the technology. During the delivery quality can be defined as a parameter of the intactness. There are two ways to control quality at the receiving part of the transaction between the company and the consumer. On one hand, there is the opportunity to make an examination of the products piece by piece and compare the results with the data come from the quality assesment and they are ascertained in the documentation of the company. (Baily and Farmer, 1994) On the other hand, a check sample can represent the condition of the whole order. By the next step of this examination the statistic knowledge of the quality managers is needed.

\section{Optimal Quantity}

Optimizing quantities in the XXI. century becomes extremely important for people working in purchasing and procurement, as each and every deal can result in huge financial consequences. Nowadays' economics do not require keeping significant stocks any more. Stocks are being replaced by information. But what do we actually mean by the term of stocks? 
Stocks are those elements of current assets, which are being consumed or streamed out from the company within a given period of time - within a business cycle (Sztanó and Vörös, 2001). In accounting means there are two types of the term inventories, self-produced stocks (incomplete production, semi-finished products and finished goods) and purchased products (materials and goods). Managing these purchased products is the hardest challenge of purchasing and procurement. Choosing the proper quantities belongs together with the ordering frequencies as well. A single order quantity is only a particular data as it does not reflect on the general ordering frequencies. In the case of such unexpected, not generaly timed orders, outstanding quantities might be required. The proper quantity as input in this situation adapts to the output produced for end-users. "Most purchases are meant for repetitive, frequent needs, where the ordered quantity does not necessarily equal to the quantity actually needed." (Baily, 1994, p82). For optimizing these orders in purchasing such mathematics based models were formed which calculate the optimal quantity to be ordered based on the order type. Stock and inventory management are remarkable areas of procurement.

\section{Optimal Time}

The right timing belongs closely to the above mentioned parts of the purchasing method. The q (quantity) and $\mathrm{t}$ (time) parameters complete each other from the purchasing point of view. "The 1990's are typified by the following purchasing objective, the so called five zeros: zero delay, zero shutdown, zero failure, zero stock and zero paperwork" (Baily, 1994, p101). Despite of this trying Just-in-time (JIT) systems are not always able to trigger a delay free carry-in. JIT system tries to create a situation in which the products are manufactured right in that quantity and at that time when the stocks of the working progress seem to be gone (Baily, 1994). The aim of JIT systems is to minimize készlettartás costs and if possible to do away with the storage. One of the advantages of JIT is the mathematical background which leads the cost decreasing process and the profitability of the company. The models and statistic methods are sometimes difficult enough to let JIT cost more than the other purchasing systems. According to the 21th's tendency this is one of the most popular systems anyway. The right timing depends not always on the achievement of the purchasing colleagues and suppliers. External environmental factors like weather adversity or catastrophes, vehicular barriers or official controls can embroil the delivery in trouble. If we reckon purchasing as a complex activity, then it can be declared that not the traditional, past-oriented methods are the most popular ones anymore (Stölzle, 2007). In line with the improvement of technology the variable methods of planning projects have been developed. The different net planning systems like CPM (Critical Path Method), MPM (Metra Potential Method) or PERT (Program evaluation and review technique) were developed first by the United States Navy in the 1950s. These are mathematical, statistical tools, used especially project management to analyze and represent the tasks involved in completing a given project. In case of interpreting purchasing as an actual project of the company, the right timing can be calculated by these tools. In business life these methods have already extended and as a reaction for that the so called Microsoft Office Project program is offered by the Microsoft company solve the planning process (Kosztyán, 2012).

\section{Optimal Supplier}

The disclosure of purchasing sources is continuously challenging people working in purchasing and procurement. Based on the fact that several steps and actions with similar priorities exist, if the domino principle prevails - as it was predicted - the entire process can fall through. After finding the preferred operative suppliers, maintaining the business connection becomes essential. In supplier relation management evaluation of suppliers and the particular 
Beáta Sz. G. PATÓ, Anna FREUND. Examination of ethical procurement through enterprise examples

PROBLEMS

OF MANAGEMENT

IN THE $21^{\text {st }}$ CENTURY

Vol. 11, No. 1, 2016

situations can provide us a huge benefit (Pató, Kopácsi \& Kreiner, 2015). Nowadays the form of a business entity determines the circle of its potential suppliers. Factories producing specific individual products or using traditional conventional technologies have limited opportunities in comparison to today's common car spread part producing enterprises. The next stage of selection following the provisional discovery is contacting potential suppliers. While asking for price quotes we gather information about price levels and we can clarify the conditions of transportation, potential price cuts at larger quantities, or even the method of the transaction. The main characteristic of healthy operation is to select the supplier after tendering the potentials. The advantage of this method is to have a documented view over the potential business partners by being able to compare their conditions. It might happen that some logistic activities will be outsourced to external logistic service providers (Pató, Kopácsi \& Kreiner, 2015). The preferences whether working with a single one or multiple suppliers have a large variability. From one point there is an opportunity to provide producing capabilities to numerous companies supporting the economy with our order - which is positive. From the other point we might make a mistake and we will not get the adequate conditions for the ordering process of our desired products if our attention gets spread among suppliers while being in touch with so many of them. On the contrary, working with only one supplier can easily cause a monopolistic situation in which the supplier has the power to assign the conditions of future deals and it can have a negative effect on our company's latitude. Correlation between companies and suppliers is also a key point. In today's business conditions interdependence within any industry sector is growing. Working within the above described no-stock environment has effects on suppliers, as for their existence it is essential to have a proper order substance, just like it is important for the buyers to have reliable suppliers.

\section{Optimal Price}

The price contains not only the basic content but also value added. So the price is a variable value, which depends on many factors such as quantity, quality, delivery deadline or even the supplier itself. Apart from these parameters attached to the price directly; social and political circumstances can affect the price as well. Pricing generally means a challenge on the producer's side. It depends on the costs of production, on the product's value for the supposed buyer, on competitors and on other market aspects, even the chosen sales channel. Among pricing methods the traditional cost-based pricing is the most common practice at producing companies, but there is also a market-driven approach where demand, the buyers' price acceptance and competitors dominate when determining the price. Examination of the product-life-cycle can also help as products (output) in the introduction, growth, maturity or decline stages cannot have the same price (Bauer, Berács, Kenesei, 2007). In the aspect of purchasing and procurement the way of pricing have lower importance, as for the buyer it is most important to negotiate a price in accordance to the company's actual economic position. In today's stage of the globalization in the world economy exchange rates play a significant role too. During the pricing process producers also consider the possible capital gain by changes in the EUR-HUF or even in the USD-HUF exchange rates. Unfortunately, this method usually affects the buyers negatively as if the deal will be realized on a higher exchange rate the higher price of the product will have to be paid by the buyer. From the history it is evident that prices are dependent on many internal and external factors. The required information can be gathered from public price lists, from on-demand internal price lists or in case of large quantities from traditional offers. At the end the synthesis prevails from big amounts of analyzed data as the purchase price marks the decision making, just like in other units of the company, purchasing and procurement aim to be cost-efficient. 
Due to the quick changes of the globalized world it is difficult to imagine that anything (any financial method) could be fixed and assured. It is valuable to talk about the options which can try to assure the fewest risk by the financial transactions of a company. There are international financial opportunities to assure the future happenings. The so called pegged exchange (german: Devisentermingeschäft) is one of these. The exchange rate can be fixed at an optimal position and the transaction will proceed at this rate. The company will bear some kind of loss, however, the ratio of this loss is calculable. Price-variation can't be a disturbing factor because of the before activity of the corporation. Many international financial options are reachable for the companies, but the popularity of them depends on their impact for the financial safety of the organizations. The Risk Management is supposed to cope with these difficult decisions on how to keep the company safe. To lighten the consequence of the risks they have to find out well functioning financial models for the companies. Hardly had a Risk Manager found a solution, when the other problem, the question of the partner's reliability raised. Fortunately there is a way to have positive results in this direction as well. The letter of credit has the role of a guaranteed parameter. Both the importer and the exporter ask their banks to interpose and stand as a security for their debts. The tool of this method is the accreditive (german: Akkreditiv) which documents the delivery and the financial transaction movements. Accreditives serve as an insurance for both partners and can be required from the banks with variable conditionals. (Laubscher, 1987)

\section{The Relationship Between Ethics and Economy}

After having introduced the process of purchasing, the economic role of Ethics will be detailed by the writers. The Greek ethosz means essentially the totality of norms which are destined for triggering right choices and action. Basically moral means a judgement about right and false human behaviour. Moral, as one of the human action's characteristics, wouldn't have stayed alive during so many centuries, if the creator agent (society) hadn't developed it. The existence of moral is therefore thanked to society and the improvement of the single societies (Boda, 2001). To monitor, analyse and systematize this norm system the philosophical discipline, Ethics has been established. Ethics includes all of the studies about moral until now. It has many impulses and is affected by several other disciplines like philosophy, theology, psychology, sociology and indirect economics, management and other not just social studies. Moral and the norm system are closely connected to each other and to the collecting concept, Ethics.

On the second figure the frame of reference in case of Ethics and its elements can be seen.

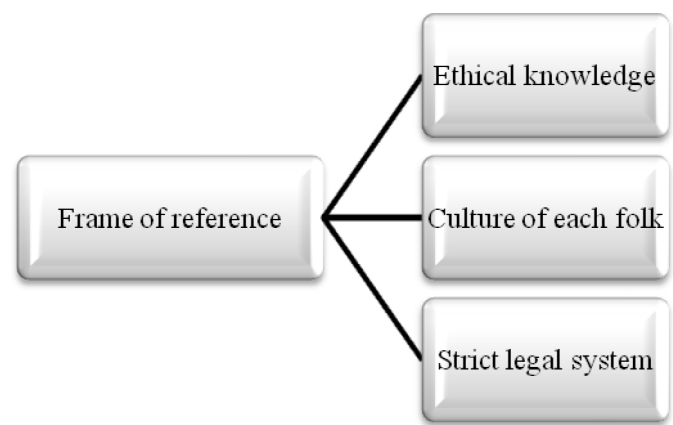

Figure 2: Components of the frame of reference (based on Turay, 2000, pp3743). 
Beáta Sz. G. PATÓ, Anna FREUND. Examination of ethical procurement through enterprise examples

PROBLEMS

OF MANAGEMENT

IN THE $21^{\text {st }}$ CENTURY

Vol. 11 , No. 1,2016

On one hand, Ethics has an examiner, fact-finding and researcher role in the scientific world. On the other hand, critics about the found information and the opportunity to develop the current moral norm system, is declared by Ethics (Hársing, 1995). The conformity to the above described requirement system is one of the examined parts from the economic point of view. The tools of ethics can help us to chart the relations between the earlier mentioned purchasing partners. As a consequence it is cleared, that there can exist disagreements between the signatories based on differences in nation's behaviour, culture, traditions or just on the generation gap. Because of this fact there is no unified perfect ethical behaviour of companies, because they have to meet different expectations.

The importance of ethics can be found mostly in coordinating the human existence. The instruction, which helps us in the daily chaos, is destined for the differentiation of right and incorrect actions. Moral is similar to a guidance, but can be called a really subjective lifestyle guidance. On the second figure the components of the moral frame of reference are illustrated. After having organized all of the found information, the right activities and behaviours are picked and a correctly composed system is given to the potential consumer. From this point it depends on the individual, if he takes or not the opportunity and applies the studies. The acceptance of the ethical studies in the economy is questionable because every business participant is concerned with it but from a different kind of view.

\section{Methodology of Research}

\section{Introducing the Problematic}

Considering the economic and corporation aspects, it can be ascertained that the ethical behaviour, as a conscious action of the organization can't be ostensive. It isn't a clear choice to make a decision about the phenomenon of ethics in business life. If it seems to be gone to waste or exactly contrarily it has already started to escalate again, can't be determined easily. The taut economic competition creates an opportunity for the economic organizations to act with real or fake ethical appearance. No one cares about the consequence of the fake ethical behaviour so there is a free way for the companies not to choose the right solution. But is it worth it for them? Are there corporations who pretend to be ethical instead of having real ethical values? From there the most important question of the study is if there are ethical values at company's procedure or only the fake signs of them are demonstrated for the public?

The authors tried to explore the power relations relative to the authenticity of the monitored companies' ethical behaviour. The research has the aim of clearing up how much the widely featured purchasing attitude of the companies is a surface activity or an ethical behaviour based on real values.

\section{Research Considerations}

The ethical questions of purchasing were analysed by qualitative methods because of the hope of getting to know new opportunities in the topic with the help coming from the case studies.

The case studies are based on the result of the exploratory research, which included a structured interview as a tool of the primer research element.

During the exploratory research 3 companies were randomly selected. The headquarters of the invited organizations are in the surroundings of Veszprém ${ }^{1}$. This sampling is not representative but every corporation is different in something from the other ones, for example in branch of industry, growth, age or market share...etc. As a secondary research tool the for us

1 Veszprém: A bigger town located in Hungary 
transmitted documents, like code of conducts, corporation operational regulations, newspapers or other publications and the websites of the companies' were studied by the authors.

Two main questions have been raised referring to the monitored focus area, purchasing.

Table 1. The main research questions.

\begin{tabular}{|c|c|c|c|c|}
\hline Questions & Description & Hypothesis & Description & Methodics \\
\hline Q-1 & $\begin{array}{l}\text { What are the charac- } \\
\text { teristics which refer to } \\
\text { the ethical purchasing } \\
\text { methods by a company? }\end{array}$ & $\mathrm{H} 1$ & $\begin{array}{l}\text { It can be clearly seen } \\
\text { in the intern and extern } \\
\text { communication of the } \\
\text { corporation that they follow } \\
\text { an ethical way in their } \\
\text { business actions. }\end{array}$ & $\begin{array}{l}\text { Questions of the } \\
\text { structured interview } \\
6 .-7 ., 10 ., 14 .\end{array}$ \\
\hline Q-2 & $\begin{array}{l}\text { Because of which impact } \\
\text { do the questioned com- } \\
\text { panies follow the ethical } \\
\text { principles? }\end{array}$ & $\mathrm{H} 2$ & $\begin{array}{l}\text { The questioned compa- } \\
\text { nies follow the ethical } \\
\text { principles part because } \\
\text { of the pressure of society, } \\
\text { and part due to their own } \\
\text { conviction. }\end{array}$ & $\begin{array}{l}\text { Questions of the } \\
\text { structured interview } \\
7 ., 10 ., 12 ., 13 .\end{array}$ \\
\hline
\end{tabular}

For both examined questions answers are given based on the results of the structured interviews.

The case studies are composed through the information gained by the examined enterprises in the period 2015-2016. So the validity tar of the research appertains to the examined companies and the indicated period.

The parameters of the examined enterprises are seen in Table 2. underneath.

Table 2. Introducing of the examined enterprises.

\begin{tabular}{llllll}
\hline $\begin{array}{l}\text { Appellation of } \\
\text { the examined } \\
\text { companies }\end{array}$ & $\begin{array}{l}\text { Number of } \\
\text { employees } \\
\text { (person) }\end{array}$ & Sector & $\begin{array}{l}\text { Year of establish- } \\
\text { ment }\end{array}$ & $\begin{array}{l}\text { Producer/ } \\
\text { Service }\end{array}$ & $\begin{array}{l}\text { Multi-national/ } \\
\text { SME }\end{array}$ \\
\hline Co.1. & $500-999$ & $\begin{array}{l}\text { Porcelain } \\
\text { industry }\end{array}$ & 1992 & Producer & SME \\
\hline Co.2. & $20-49$ & Plastics Industry & 2004 & Producer & SME \\
\hline Co.3. & $2000-4999$ & $\begin{array}{l}\text { Automo- } \\
\text { tive industry }\end{array}$ & 1990 & Producer & Multi-national \\
\hline
\end{tabular}

SME - small and medium sized enterprises.

Source: http://www.nemzeticegtar.hu (latest download: 06.06. 2016).

The research is focused on the revealing the situation. The main goal of the research is to observe the characteristics of existence of ethical purchasing based on the examined sample. During the examination this research topic seemed to be really "sensitive" and as a consequence the research questions and the structured interview should have been circumspectly composed. It was important to conduct wisely the process of the research to gain honest answers from the interviewees and based on these information the currenct situation could be revealed. The following step of the research includes the further main goal of the researchers, the development 
Beáta Sz. G. PATÓ, Anna FREUND. Examination of ethical procurement through enterprise examples

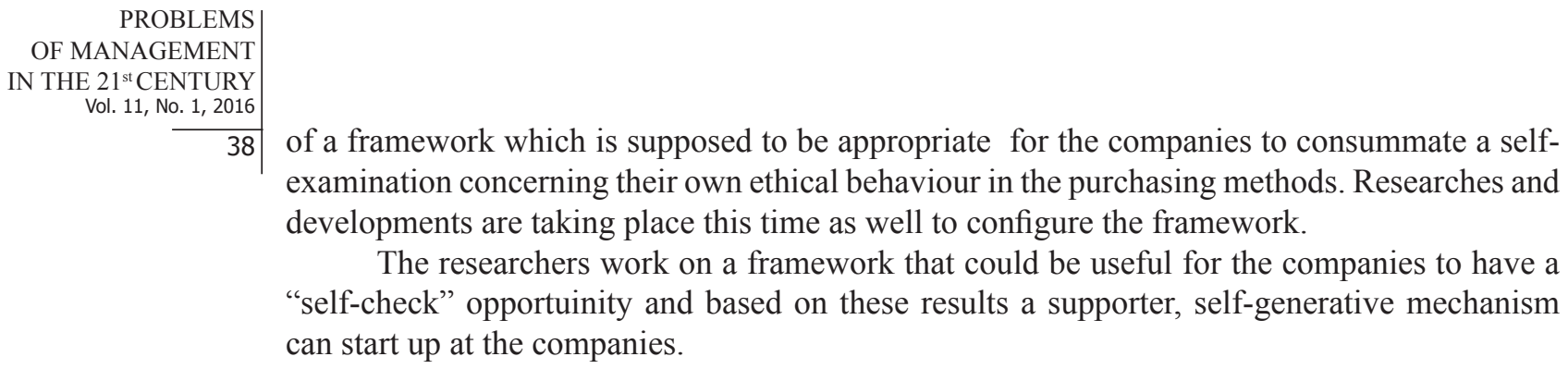

\section{Results of Research}

\section{The Examined Companies}

The goals of the research included examination of the existence of the ethical-economic combined behaviour in every questioned corporation's business activities, especially focused on the purchasing methods. The authors made this research to reach data about the current situation on the topic. If it is worth or even possible (can relevant information be obtained?) to examine the signs of the ethical behaviour is important to know because of the following steps in the study, so to continue the research of the topic but in a deeper, more complex and representative form. Every ascertainment is valid for the examined organizations.

The companies are named shortened Co.1., Co.2. and Co.3..

Case "A"

The first examined company. (later Co.1.) is a traditional Hungarian manufacture whichs main profile is the production of first class porcelain. It was founded in the $19^{\text {th }}$ century and could stay as admitted in every turbulent historical period as it always was. The recovery period of Co.1. occurred under the leadership of famous manufacturer, because his main objective was to produce high quality porcelain even measured by international standards. In 1843 he reached the manufactory's first international success due to the participation on the London World's Fair. In the following period, an active participation on the organization of world fairs and other international events was certified by the manufacture. Thanks to this thinking and business activity this porcelain has been recognized as a high quality product to the world and became a well known brand (www.herend.com latest download: 14. 08. 2015).

\section{Case "B"}

The story of Co.2. a decade back was challenging, since shortly after the founding of the company, the global economic crisis had just arrived. The then still-young producing company had to make a decision, either, like many of his contemporaries give up the operation, or continue struggling in the market. At the Co.2.'s website articles can be reached and one of them tells about the characteristics of the leadership of the company. The Managing Director says the following in the article of the Most Magazin, published in 2010: "The crisis gave us good lessons but our company has always taken steps only forwards." The continuous development appears as a kind of motto for all corporate units. The company's main activity is the production of parts, which are carried out by various molding techniques. International autoproducers are also included among their customers which is a sign that they are internationally recognized and accepted by the plastic industry (www.plasticor.hu latest download: 02.11.2015). 
Case "C"

As opposed to the previous two home companies, a multinational company was also required to be examined in the progress of the purchasing. To have this demand of the authors done, the purchasing colleagues of the Veszprémer subcompany of a multinational corporation were interviewed. The parent company was founded in the $19^{\text {th }}$ century in Germany, where the initial activity was soft rubber manufacturing. Today the brand of Co.3. is closely bound to tire producing. In the coming decades, the company has established itself constantly, so not only in the manufacture of rubber, but other aircraft and automotive parts production began, too. In 1993, the factory began its production activities in Veszprém, with developing and manufacturing of electronic braking components (http://www.continental-corporation.com latest download: 02. 11.2015).

\section{Results From the Case Studies}

In the case of the first examined company to the first research question (Q-1) intern and also extern examples can be found. Despite that the manufactory has no ethical content (code of conduct) recorded in a formal way, procedural instructions include some kind of signs and by them the ethical behaviour of Co.1. is represented in this area. Manufacturing of first-class porcelain poses serious challenges to the purchasing team who regardless of the economic, political, social, and environmental conditions still need to obtain the finest quality raw materials. In order to meet these expectations an application system based on ethical content was developed by Co.1.. These are open opportunities for everyone and this system the same conditions are set to the old suppliers, as well as to the new ones. Anyone can apply if they can meet the pre-formulated expectations of the company with their offer. Here, we can proceed immediately to the second research question. So what or whom dies it have to be thanked, that the "ethical spirit" can be found in any step of purchasing? The answer in the case of Manufacture is multiple. On one hand, in response to the legislation, on the other hand, there are regulations defined by the company referring to the products and this cooperation from the two kind of regulations ascertain the expectations and requirements which can decide about the conformity of the materials. There is a predetermined requirement system being the tool of measurement of the parameters. Besides the legal and technological requirements, it is relevant aspect, that Co.1.possesses a valuable corporate culture.

Arriving to Co.2.'s headquarter, on the walls of the building many boards are placed and with the help of them the visitors are informed about the successful tenders of the company supported by the European Union. Before questioning the interview partner these signs were seen by the author and hope of gaining positive answers were given by them too. If a company wins EU tenders, it must have other characteristics than economical ones, and these must to strengthen the company's value. The well-tested filters of the road to success as examine for example the ergonomic work environment, proper treatment or even to labour law and other authorities in compliance. According to preliminary assumptions, although they were unfounded, they have been confirmed at the preparation of the interview. As in the previous example the selection of suppliers is done by creating competition. It is more important to mention another feature of the ethical behaviour, the tool of continuous improvement, learning and intern needs of having things corrected. The company regularly holds and participates in auditing, in which operating companies of the plastics industry go through checks about the different systems of companies or their technology can be tested. These audits also reveal that striving after improvement is one of the ethical characteristics of a company. These controlling methods can be also the keystones of ethics inherent in the business life on companies. The system which is touched by healthy human needs can be bound to the studies of Ethics. The 
Beáta Sz. G. PATÓ, Anna FREUND. Examination of ethical procurement through enterprise examples

PROBLEMS

OF MANAGEMENT

IN THE $21^{\text {st }}$ CENTURY Vol. 11 , No. 1, 2016

40

existence of ethical contacts in this case is informal but their existence is clearly due to the management ethics. So this quite young company can create a corporation culture based on their important values like cooperating, improvement or correctitude. There is also one more step to have theresi real ethical signs and that is to communicate there opinion in an intern and extern direction. After having organized and communicated their values, a frame of reference could be clarified for the workers, suppliers and partners.

The third monitored organization is totally different from the other ones in structure and in the relation to Ethics as well. A formal ethical appearance is seen by the subcompany of Co.3. as well. Introductions from the international Code of Conduct are kept by the whole crew of the multinational corporation. A special section on purchasing is encountered in this document. Therefore, this example shows that the studies of ethics have been formulated specifically by this company.

There is a Compliance Management System at Co.3. and it is a special group of people who check the application of uniform standards for the company, deals with new entrant's introducing and have a kind of follow-up work because they have to re-examine the knowledge of the colleagues. The Code of Conduct and its pair the Supplier Code of Conduct are collocated and developed by this organisation. These introductions are valid for all Co.3. members respectively concerning the position in the corporation structure. The Supplier Code of Conduct includes aside from the introductions regarding the intern sphere only supplierorientated regulations too. The conclusion of the agreement will only be achieved if the selected supplier has signed it, so he accepts the details of the Supplier Code of Conduct. To compose this document, the colleagues had to consider the relevant international law. In the 4th section of the Code of Conduct requirements are ascertained regarding the importance of keeping the introduction in case of every purchasing method. Purchasing is connected with many international partners of the corporation so they are affected by their different behaviour daily. To help the colleagues making the right purchasing decisions there is a ready procedular instruction given for them. These introductions correspond to the international law and the corporation culture as well. The appearance of ethics is also a tool of CSR (Corporation Social Responsibility). Social groups can be targeted by Co.3. advertising their ethical behaviour with the help of events, their webpage or their own intern newspaper. It is clearly seen that goodwill is one of the most important phenomena in their business life and ethical behaviour is a current tool of supporting these aims of companies.

\section{Conclusions}

Looking at the three examples following studies should be done by a more complex and relevant analysis. We could see that there are the surface sings of ethical behaviour but the real aim of this hasn't been justified. The three monitored company believe in their corporations culture, and ethical behaviour is just hidden in it. Opposite of that, the appearance of this value is a positive feedback. Some signs of striving after the co-existence of economical, costefficient purchasing and Ethics are seen and accepted. The interests are not to be neglected in this case, because today's equivalent of ", honorable gentlemen" couldn't be defined in this study. The importance of conformity seems to be more relevant for the companies than quality. Conformity and the belonging regulation systems lead the companies to a situation in which they aren't able to subtract from the systems and can't deal with the importance of satisfaction from value added requirements. That means a difficulty for the corporations in finding their ethical way. 


\section{References}

Baily, P., \& Farmer, D. (1994). Beszerzés, Stratégia és menedzsment [Procurement, strategy and management]. Budapest, Müszaki Könyviadó, p. 16, 69-70, 82, 95, 101.

Bauer, A., Berács, J., \& Kenesei, Zs. (2007). Marketing alapismeretek [Marketing]. Aula Kiadó, pp. 191214.

Boda, L. (2001). Természetjog, erkölcs, humánum - A jogbölcselet etikai látóhatára [Natural law, moral, humanity - The ethical horizon of the theory of the law]. Szent István társulat. Az Apostoli Szentszék Könyvkiadója, p.77.

Borgulya, Á., \& Somogyvári, M. (2007). Kommunikáció az üzleti világban [Comminication in business world]. Akadémiai Kiadó, pp.85-99.

Gaál, Z., \& Szabó, L. (2007). A menedzsment alapjai [Management]. Pannon Egyetemi Kiadó, pp. 43-59.

Hársing, L. (1995). Bevezetés az etikába [Introduction to ethics]. Budapest, Nemzeti Tankönyvkiadó. In: Szegedi, K. (2006). Üzleti etika [Business ethics]. Perfekt Gazdasági Tanácsadó Oktató és Kiadó Zrt., p. 24.

Kosztyán, Zs. T. (2012). Challanges of the project planning methods in the 21 st century. Problems of Management in the 21st Century, 2 (5), 46-60.

Kovács, Z. (2004). Logisztika [Logistics]. Veszprém, Pannon Egyetemi Kiadó, p. 133, 142-218.

Kovács, Z., \& Pató, B. Sz. G. (2014). Impacts of extreme weather in supply chains. Időjárás Ouarterly Journal of the Hungarian Meteorological Service, 118 (3), 283-291.

Pató, B. Sz. G., \& Szabó, L. (2013). Külső logisztikai szolgáltatások/szolgáltatók vizsgálata [The research of external logistics services]. Vezetéstudomány, XLIV (6), 87-94.

Pató, B. Sz. G., Kopácsi, E., \& Kreiner, B. (2015). Beszállító értékelés folyamatának elemző kutatása. [Analyst research on supplier evaluation process]. In Vállalkozásfejlesztés a XXI. században tanulmánykötet, Óbudai Egyetem, Keleti Károly Gazdasági Kar, pp.57-76. Retrieved from http:// kgk.uni-obuda.hu/sites/default/files/04_Pato_Kopacsi_Kreiner.pdf.

Pató, B. Sz. G. (2015). The 3D job description. Journal of Management Development, 34 (4), 406 - 442.

Laubscher, H. (1987). Internationale Projektfinanzierung [Internation project finance]. Technologie \& Management, 3, 22-29.

Majoros, P., Barta P., \& Zimler T. (1999). Iparvállalatok beszerzés-gazdaságtana [Procurement-economy of companies]. Budapest, Müszaki könyvkiadó - Magyar Minőségi Társaság, p.13-51.

Stölzle, W. (2007). Beschaffung als Herausforderung für das Controlling [Procurement as a challange for controlling]. Controlling \& Management, ZfCM, 51 (3), 200-203.

Szegedi, K. (2006). Üzleti etika [Business ethics]. Perfekt Gazdasági Tanácsadó, Oktató és Kiadó Zrt., p. 24.

Sztanó, I., \& Vörös, M. (2001). Számviteli alapismeretek [Accounting]. SALDO Pénzügyi Tanácsadó és Informatikai Rt., pp. 79-90.

Turay, A. (2000). Az ember és az erkölcs [Person and moral]. Szeged, Agapé, Ferences Nyomda és Könyvkiadó Kft., pp. 5-6, 37-43.

Veress, G., Birher, N., \& Nyilas, M. (2010). A minöségbiztositás filozófiája [The philosophy of quality assurance]. Budapest, Jel Könyvkiadó, p. 24-32.

Herend porcelaine (2015). Retrieved 11.08.2015. from http://herend.com.

PLASTICOR injection moulding Ltd. (2015). Retrieved 12.10.2015 from http://www.plasticor.hu.

Continental Corporation (2015). Retrieved 12.10.2015 from http://www.continental-corporation.com/ www/portal_com_en.

Nemzeti Cegtar (2016). Retrieved 06.06. 2016 from http://www. nemzeticegtar.hu.

The TÜV Rheinland Group (2015). Retrieved 12.10.2015 from http://tuv.com. 
Beáta Sz. G. PATÓ, Anna FREUND. Examination of ethical procurement through enterprise examples

PROBLEMS

OF MANAGEMENT

IN THE $21^{\text {st }}$ CENTURY

Vol. 11, No. 1, 2016

42
Advised by Grzegorz Michalski, Wroclaw University of Economics, Poland

Received: May 19, 2016

Accepted: June 15, 2016

Beáta Sz. G., Pató PhD., Associate Professor, University of Pannonia, Egyetem u. 10, 8200 Veszprém, Hungary.

E-mail: patog@vnet.hu

Website: http://www.gtk.uni-pannon.hu

Anna Freund Technical Management Student, University of Pannonia, Egyetem u. 10, 8200

Veszprém, Hungary.

E-mail: freund.anna@amicustrade.hu

Website: http://www.gtk.uni-pannon.hu 